\title{
Cerebral Infarction Caused by Pituitary Apoplexy: Case Report and Review of Literature
}

\author{
Pitüiter Apopleksiye Bağlı Beyin Infarktüsü: Olgu Sunumu ve \\ Literatürün Gözden Geçrilmesi
}

\author{
Chenxi ZHANG ${ }^{1}$, Feng FENG ${ }^{2}$, Yicheng ZHU $^{3}$, Renzhi WANG ${ }^{1}$, Bing XING ${ }^{1}$ \\ ${ }_{1}^{1}$ Peking Union Medical College Hospital, Departments of Neurosurgery, Beijing, China \\ ${ }^{2}$ Chinese Academy of Medical Sciences, Departments of Radiology, Beijing, China \\ ${ }_{3}^{3}$ Peking Union Medical College, Departments of Neurology, Beijing, China
}

Corresponding Author: Bing XING / E-mail: xingbingemail@aliyun.com

\begin{abstract}
Pituitary apoplexy followed by cerebral infarction is rare. In this report, we present a 42-year-old man who had been diagnosed of pituitary adenoma presented with a sudden onset of unconsciousness, left hemiplegia and right ptosis. Investigations revealed the development of pituitary apoplexy. The extension of tumor mass compressed the supraclinoid portion of the right internal carotid artery, resulting in the cerebral infarction in the right anterior and middle cerebral artery territory. Left anterior cerebral artery territory infarction was also found, which could be caused by vasospasm provoked by pituitary apoplexy. The patient underwent decompression surgery via transsphenoidal approach after four weeks' conservative treatment, and pathological examination revealed hemorrhage and necrosis of the pituitary adenoma. His symptoms improved within five months' follow-up. Since pituitary apoplexy producing cerebral infarction is rare, clinicians should be alert to that possibility, and delayed transsphenoidal surgery following conservative management with steroids is the appropriate management of such an occurrence.
\end{abstract}

KEYWORDS: Cerebral infarction, Compression, Internal carotid artery, Pituitary apoplexy, Vasospasm

öz

Pitüiter apopleksi sonrasında beyin infarktüsü nadirdir. Burada, ani başlangıçlı bilinç kaybı, sol hemipleji ve sağ pitozis ile başvuran ve hipofiz adenomu tanısı alan 42 yaşındaki bir erkek hasta sunulmuştur. İncelemeler pitüiter apopleksi gelişimini ortaya koydu. Tümör kitlesinin uzantısı sağ anterior ve orta serebral arter bölgesinde serebral infarktüs ile sonuçlanacak şekilde sağ internal karotid arter supraklinoid kısmını sıkıştırmış idi. Pitüiter apopleksi tarafından tetiklenen vazospazmın neden olmuş olabileceği sol anterior serebral arter bölgesi infarktüsü de bulundu. Dört haftalık tutucu tedavi sonrasında transsfenoidal yaklaşım ile dekompresyon ameliyatı yapıldı ve patolojik muayenede hipofiz adenomu nekrozu ve kanama saptandı. Hastanın belirtileri beş aylık takip ile düzeldi. Serebral infarktüse neden olan pitüiter apopleksi nadir olduğundan klinisyenler bu olasılık açısından dikkatli olmalıdır. Böyle bir durumda uygun tedavi ve steroidler ile tutucu tedavi sonrasında geciktirilmiş transsfenoidal cerrahidir.

ANAHTAR SÖZCÜKLER: Serebral infarktüs, Kompresyon, İnternal karotid arter, Pitüiter apopleksi, Vazospazm

\section{INTRODUCTION}

Pituitary apoplexy is an acute clinical syndrome typically characterized by a sudden headache, visual impairment, altered consciousness and ocular palsy. Hemorrhage and/or infarction of pituitary adenomas are the most common causes. Pituitary apoplexy occurs in $0.6-10 \%$ of patients with pituitary adenomas (5). However, pituitary apoplexy complicated by cerebral infarction is rare. Here, a case of pituitary apoplexy followed by cerebral infarction is reported.

\section{CASE REPORT}

A 42-year-old man presented with an acute high fever $\left(40^{\circ} \mathrm{C}\right)$. Several hours later, he developed a sudden onset of unconsciousness after urinating and admitted to our hospital. He had just been clinically diagnosed of pituitary adenoma 2 weeks ago after suffering from headache for 8 months (Figure 1). On admission, his score of GCS (Glascow Coma Scale) was 4/15(E2V1M1). His body temperature was $38.7^{\circ} \mathrm{C}$. Physical examination revealed anisocoria (right $>$ left), right ptosis and impaired light reflex. His neck was stiff and Babinski sign on the left side was positive. Computerized tomography (CT) scans of the brain showed cerebral ischemia in the bilateral anterior and right middle cerebral artery territory (Figure 2). Transcranial Doppler ultrasound (TCD) detected decreased blood flow velocity within the bilateral anterior and right middle cerebral arteries. T1-weighted nonenhanced Magnetic resonance imaging (MRI) demonstrated intratumoral hemorrhage in the hypophysial fossa invading the cavernous sinus (Figure 3A). And T2-weighted MRI showed the infarction of bilateral anterior and right middle cerebral artery territory (Figure 3B). Magnetic resonance angiography 
(MRA) confirmed narrowing of the supraclinoid segment of the right internal carotid artery (Figure 4A). Serum examination revealed a slight decrease in free triiodothyronine and free thyroxine while corticoid and growth hormone levels were normal.

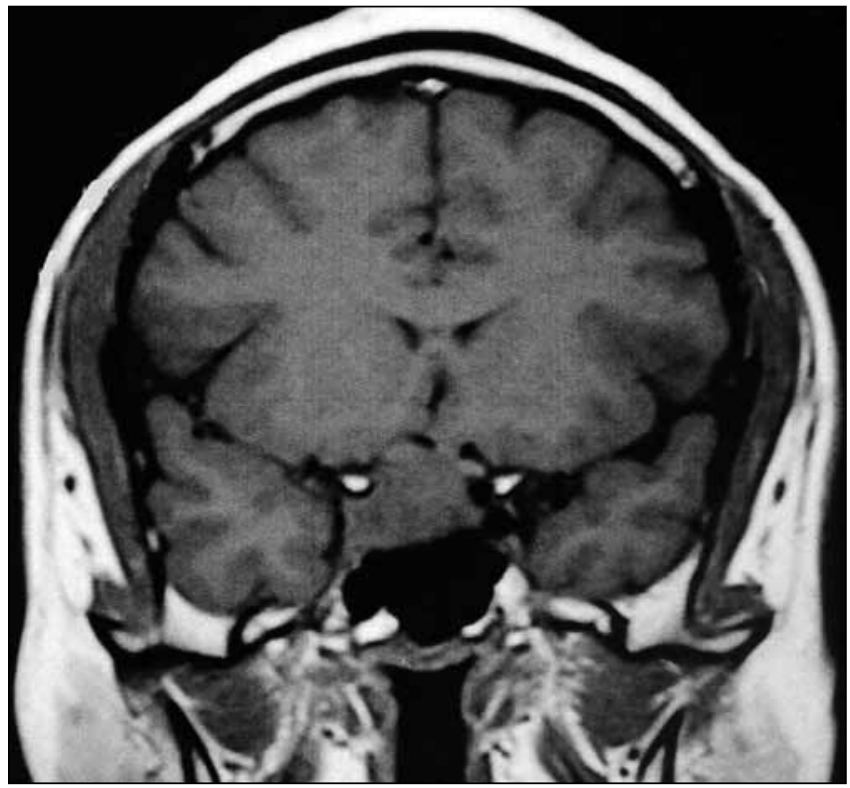

Figure 1: Coronal T1-weighted non-enhanced MRI showing a pituitary mass with isointensity before the acute attack.

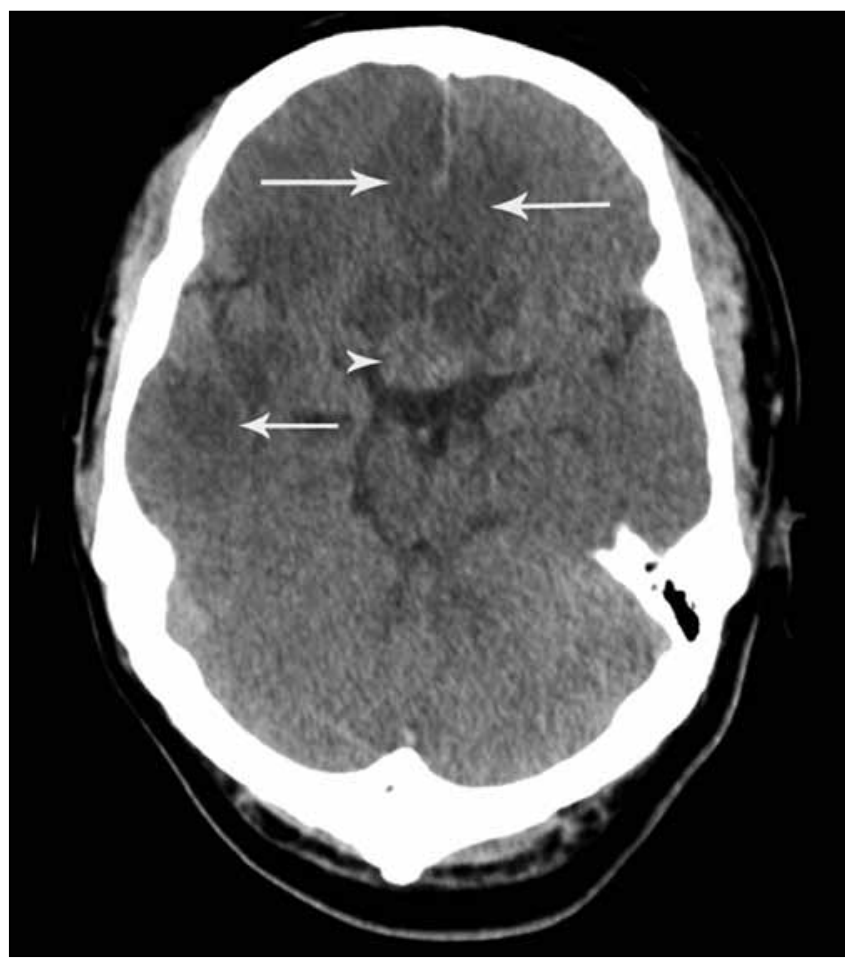

Figure 2: Computerized tomography scan showing massive low density area in the bilateral anterior and right middle cerebral artery territory (arrow) with a heterogeneous density lesion occupying the suprasellar cistern (arrowhead).
The patient was initially treated with mannitol and steroids for massive cerebral infarction and levothyroxine sodium for hypopituitarism. His temperature decreased to $37.4^{\circ} \mathrm{C}$ and his consciousness improved that his GCS score reached nine (E2V1M6) during the next week. The muscle strength of his right limbs was in grade $\mathrm{V}$, while the left was still in paralysis. His symptoms of cranial nerve palsy persisted. Four weeks after the onset, transsphenoidal surgery was performed to remove the tumor for decompression. Pathological examination revealed hemorrhage and necrosis of the pituitary adenoma.
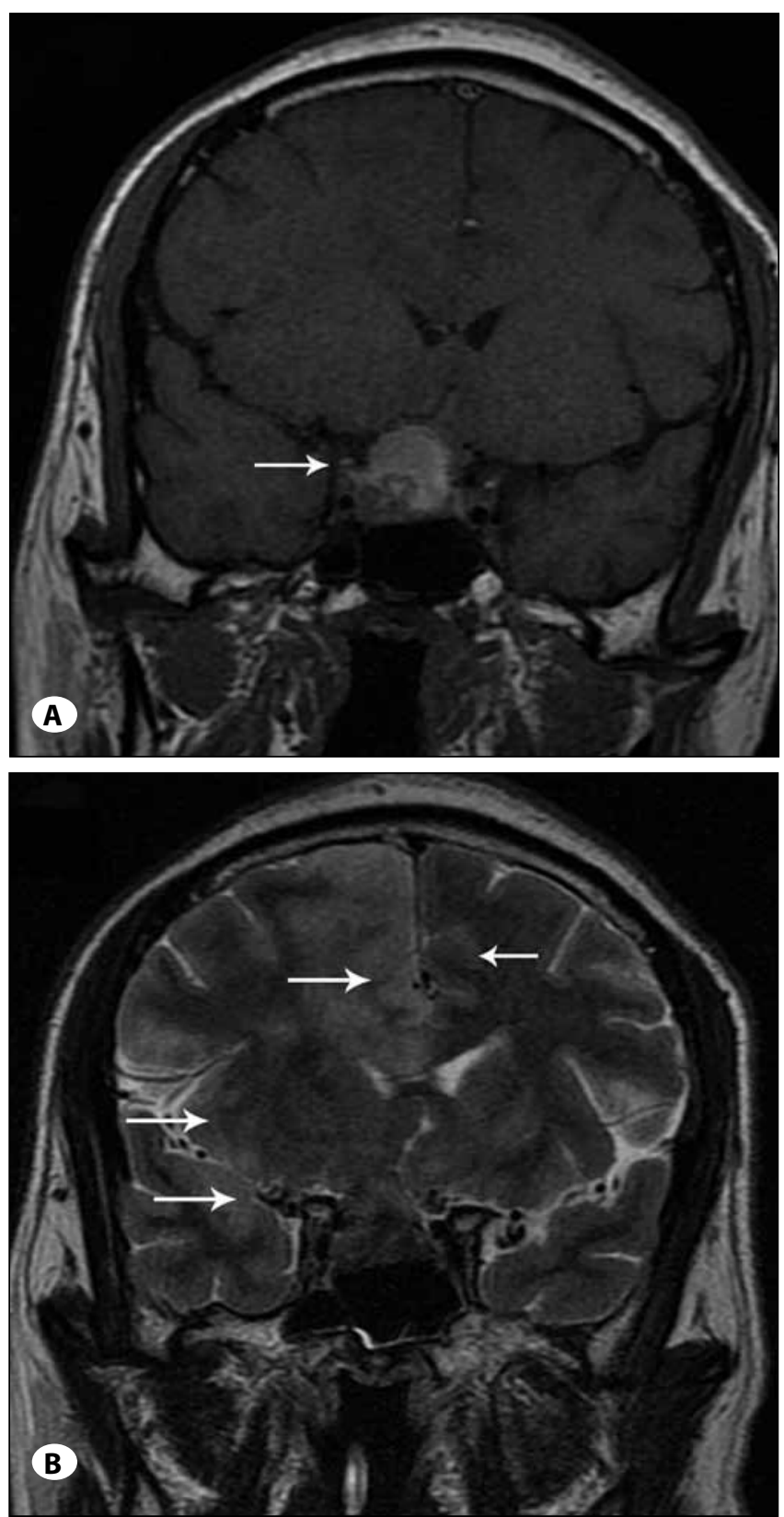

Figure 3: Coronal T1-weighted non-enhanced MRI showing focal high signal intensity around the cavernous portion of right internal carotid artery (A, arrow), while Coronal T2-weighted MRI showing high signal intensity in the bilateral anterior and right middle cerebral artery territory (B, arrow). 
Immunohistochemical staining results demonstrated it negative for all the anterior pituitary hormone.

Postoperatively, his right ptosis and light reflex improved rapidly. One week after the operation, MRA was carried out, confirming the decompression of the narrowed internal carotid artery (Figure 4B). The motor power of his left lower limb recovered to grade $\mathrm{V}^{-}$within five months after the operation, and that of the left upper to grade II.

\section{DISCUSSION}

Sudden onset of headache, vomiting, visual impairment and decreased consciousness are common complications of pituitary apoplexy, while cerebral infarction secondary to pituitary apoplexy is rare. To our best knowledge, only 14 cases have been reported since $1952(3,4,6,7,9-13,15-$
18, 20). The clinical features of these cases are summarized in Table I, II. All the cases reported before were male, with ages ranging from 15 to 77 years. This demographic feature was in consistent with epidemiological studies on pituitary apoplexy, which showed men were more commonly affected with ages reported between 15 and 90 years $(14,19)$. Motor symptoms were found in almost all the cases except the one reported by Pozzati et al. (15), where the patient instead developed central facial weakness. Consciousness alteration and cranial nerve palsy were also common complications. As to the affected vessels, the cavernous portion or supraclinoid portion of internal carotid artery, anterior cerebral artery and middle cerebral artery were most likely to be involved.

In our case, the patient, a middle-aged male, lost consciousness and developed left hemiplegia and right cranial III nerve palsy

Table I: Reported Cases of Cerebral Infarction Caused by Vasospasm Secondary to Pituitary Apoplexy

\begin{tabular}{|c|c|c|c|c|c|}
\hline Reference & Age/Sex & Symptoms & Vessels Involved & Treatment & Outcome \\
\hline Pozzati et al., 1987 (15) & $15 / M$ & $\begin{array}{l}\text { Reduced consciousness, } \\
\text { right cranial III/VI nerve } \\
\text { palsy, left central facial } \\
\text { weakness }\end{array}$ & Bilateral ICA & $\begin{array}{l}\text { Conservative } \\
\text { care }\end{array}$ & Improvement \\
\hline Itoyama et al., 1990 (9) & $45 / \mathrm{M}$ & $\begin{array}{l}\text { Reduced consciousness, } \\
\text { right hemiparesis, visual } \\
\text { disturbances }\end{array}$ & Left ACA and left MCA & Delayed TSA & Improvement \\
\hline Rodier et al., 2003 (16) & $35 / M$ & $\begin{array}{l}\text { Left hemiplegia, frontal } \\
\text { syndrome with apathy, } \\
\text { unconsciousness }\end{array}$ & $\begin{array}{l}\text { right and left } A C A \text {, } \\
\text { right } M C A\end{array}$ & $\begin{array}{l}\text { Decompression } \\
\text { surgery\# }\end{array}$ & Improvement \\
\hline Akutsu et al., 2004 (3) & 29/M & $\begin{array}{l}\text { Reduced consciousness, } \\
\text { transient right hemiplegia }\end{array}$ & Left $A C A$ and MCA & Early TSA & Improvement \\
\hline Present case, 2012 & $42 / \mathrm{M}$ & $\begin{array}{l}\text { Left hemiplegia, } \\
\text { unconsciousness, right } \\
\text { cranial III nerve palsy }\end{array}$ & $\begin{array}{l}\text { Right ICA } \\
\text { (supraclinoid portion) } \\
\text { Left ACA }\end{array}$ & Delayed TSA & Improvement \\
\hline
\end{tabular}

ICA: internal carotid artery, ACA: anterior cerebral artery, MCA: middle cerebral artery, TSA: transsphenoidal approach, \#: the operation method was not described.
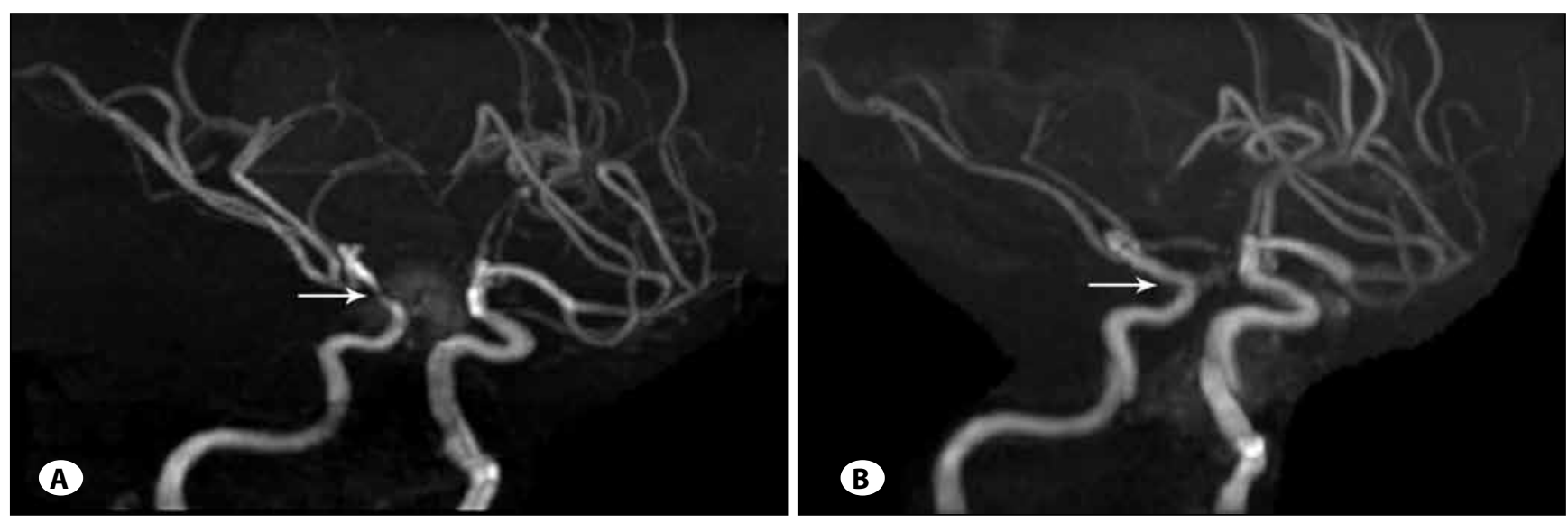

Figure 4: MRA showing the stenosis of the supraclinoid segment of right internal carotid artery compressed by the hemorrhagic pituitary mass (A, arrow), and postoperative MRA illustrating decompression and restoration of the right internal carotid artery (B, arrow). 
during the course of the illness. The right internal carotid artery and left middle cerebral artery were confirmed to be involved in this case, which was in accordance with the clinical features mentioned above.

Furthermore, there are two possible mechanisms of cerebral infarction caused by pituitary apoplexy that have been suggested: vasospasm and mechanical compression. Vasospasm may be caused by subarachnoid hemorrhage, the release of vasoactive substances from a pituitary adenoma or hypothalamic damage (2). Four cases attributed to vasospasm are listed in Table I. Bilateral cerebral arteries are theoretically speculated to be involved in cases of vasospasm, and angiography can verify the existence of vasospasm $(3,9)$. Mechanical compression is caused by the extension of the tumor mass. In patients with pituitary apoplexy, intrasellar pressure will be markedly elevated to a mean value of 47 $\mathrm{mmHg}$, high enough for the lesion to invade the cavernous sinus and cause narrowing or occlusion of internal carotid artery (21). What's more, the bony structure surrounding the cavernous sinus spares no compensatory space for the

Table II: Reported Cases of Cerebral Infarction Caused by Mechanical Compression of Major Vessels Secondary to Pituitary Apoplexy

\begin{tabular}{|c|c|c|c|c|c|}
\hline Reference & $\begin{array}{l}\text { Agel } \\
\text { Sex }\end{array}$ & Symptom & $\begin{array}{l}\text { Vessels } \\
\text { Involved }\end{array}$ & Treatment & Outcome \\
\hline $\begin{array}{l}\text { Schnitker and Lehnert, } \\
1952 \text { (18) }\end{array}$ & $65 / M$ & $\begin{array}{l}\text { Left hemiplegia, } \\
\text { reduced consciousness }\end{array}$ & Right MCA & $\begin{array}{l}\text { Conservative } \\
\text { care }\end{array}$ & Death \\
\hline $\begin{array}{l}\text { Rosenbaum et al., } \\
1977 \text { (17) }\end{array}$ & 77/M & $\begin{array}{l}\text { Left hemiparesis, } \\
\text { unconsciousness }\end{array}$ & $\begin{array}{l}\text { Right ICA } \\
\text { (supraclinoid } \\
\text { portion) }\end{array}$ & Early craniotomy & Death \\
\hline $\begin{array}{l}\text { Majchrzak et al., } \\
1983 \text { (13) }\end{array}$ & 29/M & $\begin{array}{l}\text { Left hemiparesis, } \\
\text { unconsciousness }\end{array}$ & Right ACA & $\begin{array}{l}\text { Delayed } \\
\text { craniotomy }\end{array}$ & Improvement \\
\hline $\begin{array}{l}\text { Bernstein et al., } \\
1984 \text { (4) }\end{array}$ & $48 / \mathrm{M}$ & $\begin{array}{l}\text { Left hemiparesis, } \\
\text { Reduced consciousness }\end{array}$ & $\begin{array}{l}\text { Bilateral ICA } \\
\text { (cavernous } \\
\text { portion) }\end{array}$ & Early TSA & Improvement \\
\hline $\begin{array}{l}\text { Clark et al., } \\
1987(7)\end{array}$ & $40 / M$ & $\begin{array}{l}\text { Right hemiplegia, dysphagia, } \\
\text { right facial palsy }\end{array}$ & $\begin{array}{l}\text { Left ICA } \\
\text { (supraclinoid } \\
\text { portion) }\end{array}$ & $\begin{array}{l}\text { Conservative } \\
\text { care }\end{array}$ & $\begin{array}{l}\text { Extensive } \\
\text { infarct }\end{array}$ \\
\hline $\begin{array}{l}\text { Lath and Rajshekhar, } \\
2001 \text { (11) }\end{array}$ & $40 / \mathrm{M}$ & $\begin{array}{l}\text { Left hemiplegia, reduced } \\
\text { consciousness, left facial palsy, } \\
\text { vision loss }\end{array}$ & Right ACA & Early TSA & Death \\
\hline $\begin{array}{l}\text { Rodier et al., } \\
2003 \text { (16) }\end{array}$ & $35 / M$ & $\begin{array}{l}\text { Left hemiplegia, frontal } \\
\text { syndrome with apathy, } \\
\text { unconsciousness }\end{array}$ & $\begin{array}{l}\text { Bilateral ACA, } \\
\text { Right MCA }\end{array}$ & $\begin{array}{l}\text { Decompression } \\
\text { surgery }{ }^{\#}\end{array}$ & Improvement \\
\hline $\begin{array}{l}\text { Kurschel et al., } \\
2005 \text { (10) }\end{array}$ & $61 / M$ & Unconsciousness & Bilateral ICA & $\begin{array}{l}\text { Conservative } \\
\text { care }\end{array}$ & Death \\
\hline $\begin{array}{l}\text { Yang et al., } \\
2008(20)\end{array}$ & $43 / M$ & $\begin{array}{l}\text { Left hemiplegia, visual } \\
\text { disturbances }\end{array}$ & $\begin{array}{l}\text { Right } \\
\text { ICA(cavernous } \\
\text { portion) }\end{array}$ & Early TSA & Improvement \\
\hline $\begin{array}{l}\text { Lill et al., } \\
2009 \text { (12) }\end{array}$ & $59 / \mathrm{M}$ & $\begin{array}{l}\text { Left hemiparesis, } \\
\text { unconsciousness, right cranial } \\
\text { III and IV nerves palsy }\end{array}$ & Bilateral ICA & $\begin{array}{l}\text { Conservative } \\
\text { care }\end{array}$ & Death \\
\hline $\begin{array}{l}\text { Chokyu et al., } \\
2011 \text { (6) }\end{array}$ & $50 / \mathrm{M}$ & $\begin{array}{l}\text { Left hemiparesis, right cranial III } \\
\text { nerve palsy }\end{array}$ & $\begin{array}{l}\text { Right } \\
\text { ICA(cavernous } \\
\text { portion) }\end{array}$ & Delayed TSA & Improvement \\
\hline Present case, 2012 & $42 / \mathrm{M}$ & $\begin{array}{l}\text { Left hemiplegia, } \\
\text { unconsciousness, right cranial } \\
\text { III nerve palsy }\end{array}$ & $\begin{array}{l}\text { Right ICA } \\
\text { (supraclinoid } \\
\text { portion) } \\
\text { Left ACA }\end{array}$ & Delayed TSA & Improvement \\
\hline
\end{tabular}

ICA: internal carotid artery, ACA: anterior cerebral artery, MCA: middle cerebral artery, TSA: transsphenoidal approach, \#: the operation method was not described. 
compressed vessels, which further exacerbate compression (20). Eleven cases due to mechanic compression are displayed in Table II, one of which actually shares both mechanisms.

In the present case, MRI demonstrated intratumoral hemorrhage intruding the cavernous sinus and MRA revealed the result of invasion, narrowing of the supraclinoid segment of the right internal carotid artery, which led to the development of cerebral infarction causing hemiplegia. Therefore, mechanical compression played the main role in the right cerebral infarction. However, as to the infarction of left anterior cerebral artery territory, little evidence of compression was found in MRI or MRA images. We speculated that it could be caused by transient vasospasm that was relieved before performing MRA, leaving no signs of vasospasm in the angiography.

Because of the rarity of cerebral infarction following pituitary apoplexy, clinicians should pay much attention to the differential diagnosis and early management. There is a high risk of misdiagnosing these cases as a common ischemic stroke that is often caused by thrombosis or embolism. The recommended early management for this kind of ischemic stroke includes antiplatelet therapy and sometimes even thrombolysis therapy (1). However, if the ischemic stroke is caused by hemorrhagic pituitary apoplexy, such treatment will promote further hemorrhage into the damaged tissue and the patient's condition will deteriorate. To avoid such tragedy, emergent cranial MRI is needed. Cranial MRI has a better capability of identifying pituitary apoplexy than cranial CT. In our case, the initial cranial CT did not show definite hemorrhage or infarction in the pituitary. Only after the performance of emergent cranial MRI were we able to confirm the existence of pituitary apoplexy and find the relationship between pituitary apoplexy and cerebral infarction. When patients with a history or symptoms of pituitary adenoma develop ischemic stroke, emergent cranial MRI should be performed to rule out pituitary apoplexy, which has a great impact on the formulation of the treatment plan.

The primary goal of treatment is to reduce the intratumoral pressure (20). Of the five who received conservative care in the literature, four died or developed extensive infarction and only one improved. Nine of the fourteen patients mentioned above were operated upon, two via a transcranial approach, six via a transsphenoidal approach and one via an undefined decompression approach. Seven of these had good outcome while two died. Compared to conservative management alone, surgical decompression is more advisable when patients develop severe visual or mental impairment or deteriorate progressively with focal ischemic deficit. However, the optimal timing for the surgical treatment is controversial (6). Early decompression surgery is often advocated in pituitary apoplexy, since it may reverse visual compromise and restore ICA blood flow (8). Of the five who received surgical decompression in the acute stage, two patients died, while all the three delayed decompression cases had a good outcome. The combined effect of the infarct and the brain edema was considered as the common cause of mortality in early decompression surgery (20). As Clark et al. suggested, the early removal of pituitary tumor increased the risk of hemorrhagic transformation following recanalization of the obstructed arteries, which might result in hemorrhagic infarction (7). Therefore, delayed decompression following conservative therapy with steroids can be a better choice.

Even though our patient developed severe conscious disturbances, he became stable and even improved to some extent after the initial conservative therapy. In account of the risk of hemorrhage infarction, we decided to perform a delayed surgical decompression through the transsphenoidal route, which resulted in the immediate improvement of the patient's oculomotor palsy and delayed recovery of his motor weakness.

In conclusion, pituitary apoplexy producing cerebral infarction is rare. Mechanical compression and vasospasm are proposed as two main mechanisms leading to this complication. Both seem to have played a role in the present case. Emergent cranial MRI is suggested in patients with pituitary adenoma who present with signs of cerebral infarction. Delayed decompression surgery through the transsphenoidal approach following conservative management with steroids is appropriate as our case demonstrates.

\section{REFERENCES}

1. Adams HP Jr, del Zoppo G, Alberts MJ, Bhatt DL, Brass L, Furlan A, Grubb RL, Higashida RT, Jauch EC, Kidwell C, Lyden PD, Morgenstern LB, Qureshi Al, Rosenwasser RH, Scott PA, Wijdicks EF: Guidelines for the early management of adults with ischemic stroke: A guideline from the American Heart Association/American Stroke Association Stroke Council, Clinical Cardiology Council, Cardiovascular Radiology and Intervention Council, and the Atherosclerotic Peripheral Vascular Disease and Quality of Care Outcomes in Research Interdisciplinary Working Groups: The American Academy of Neurology affirms the value of this guideline as an educational tool for neurologists. Circulation 115(20): e478-534, 2007

2. Ahmed SK, Semple PL: Cerebral ischaemia in pituitary apoplexy. Acta Neurochir(Wien) 150(11): 1193-1196, 2008

3. Akutsu $H$, Noguchi S, Tsunoda T, Sasaki M, Matsumura A: Cerebral infarction following pituitary apoplexy--case report. Neurol Med Chir (Tokyo) 44(9): 479-483, 2004

4. Bernstein M, Hegele RA, Gentili F, Brothers M, Holgate $R$, Sturtridge WC, Deck J: Pituitary apoplexy associated with a triple bolus test. Case report. J Neurosurg 61(3): 586-590, 1984

5. Cardoso ER, Peterson EW: Pituitary apoplexy: A review. Neurosurgery 14(3): 363-373, 1984

6. Chokyu I, Tsuyuguchi N, Goto T, Chokyu K, Chokyu M, Ohata K: Pituitary apoplexy causing internal carotid artery occlusion-case report. Neurol Med Chir (Tokyo) 51(1): 48-51, 2011

7. Clark JD, Freer CE, Wheatley T: Pituitary apoplexy: An unusual cause of stroke. Clin Radiol 38(1): 75-77, 1987 
8. Dogan S, Kocaeli H, Abas F, Korfali E: Pituitary apoplexy as a cause of internal carotid artery occlusion. J Clin Neurosci 15(4): 480-483, 2008

9. Itoyama Y, Goto S, Miura M, Kuratsu J, Ushio Y, Matsumoto $\mathrm{T}$ : Intracranial arterial vasospasm associated with pituitary apoplexy after head trauma--case report. Neurol Med Chir (Tokyo) 30(5): 350-353, 1990

10. Kurschel S, Leber KA, Scarpatetti M, Roll P: Rare fatal vascular complication of transsphenoidal surgery. Acta Neurochir (Wien) 147(3): 321-325, 2005

11. Lath R, Rajshekhar V: Massive cerebral infarction as a feature of pituitary apoplexy. Neurol India 49(2): 191-193, 2001

12. Lill CM, Hoch H, Dieste FJ, Vogel HP, Zipp F, Paul F: Bilateral stroke following pituitary apoplexy. J Clin Neurosci 16(12): 1670-1673, 2009

13. Majchrzak H, Wencel T, Dragan T, Bialas J: Acute hemorrhage into pituitary adenoma with SAH and anterior cerebral artery occlusion. Case report. J Neurosurg 58(5): 771-773, 1983

14. Murad-Kejbou S, Eggenberger E: Pituitary apoplexy: Evaluation, management, and prognosis. Curr Opin Ophthalmol 20(6): 456-461, 2009

15. Pozzati E, Frank G, Nasi MT, Giuliani G: Pituitary apoplexy, bilateral carotid vasospasm, and cerebral infarction in a 15-year-old boy. Neurosurgery 20(1): 56-59, 1987
16. Rodier G, Mootien Y, Battaglia F, Martinet O, Cohen E: Bilateral stroke secondary to pituitary apoplexy. J Neurol 250(4): 494-495, 2003

17. Rosenbaum, TJ, Houser OW, Laws ER: Pituitary apoplexy producing internal carotid artery occlusion. Case report. J Neurosurg 47(4): 599-604, 1977

18. Schnitker MT, Lehnert HB: Apoplexy in a pituitary chromophobe adenoma producing the syndrome of middle cerebral artery thrombosis; case report. J Neurosurg 9(2): 210-213, 1952

19. Steven JR, Karen KM: Pituitary apoplexy. In: Brooke S, Beverly MB (eds), Diagnosis and Management of Pituitary Disorders. New York: Humana, 2008: 356

20. Yang SH, Lee KS, Lee KY, Lee SW, Hong YK: Pituitary apoplexy producing internal carotid artery compression: A case report. J Korean Med Sci 23(6): 1113-1117, 2008

21. Zayour DH, Selman WR, Arafah BM: Extreme elevation of intrasellar pressure in patients with pituitary tumor apoplexy: Relation to pituitary function. J Clin Endocrinol Metab 89(11): 5649-5654, 2004 